\title{
ГІРНИЦТВО
}

УДК 624.138 .29

DOI: https://doi.org/10.26642/ten-2019-2(84)-126-132

В.В. Бойко, Д.т.н., проф.

О.В. Ган, аспір.

Науково-дослідна лабораторія з проблем сейсмічної безпеки технологічних вибухів

Інституту гідромеханіки Національної академї̈ наук Украӥни

В.Г. Кравець, д.т.н., проф.

А.Л. Ган, к.т.н., доц.

Національний технічний університет Украйни

«Київський політехнічний інститут імені Ігоря Сікорського»

\section{Спосіб приготування та добір компонентного складу спінених вибухових композицій для ущільнення просадних грунтів}

Запропоновано пристрій для приготування водонаповненої спіненої вибухової композиції, який можна використовувати в польових умовах при ущільненні просадних нестійких трунтів. Спінена водонаповнена вибухова композиція складається з аміачної селітри, поверхнево-активних речовин (ПАР) $i$ води.

Обгрунтовано спосіб приготування спіненої вибухової композииії, який полягає у змішуванні ПАР з водою, а потім з аміачною селітрою механічним шляхом у низькошвидкісному режимі без спінювання сумімі, подачу иієї суспензї під тиском до об'єкта проведення підривних робіт та дозованою аерацією його за рахунок ежектування повітря потоком сумімі з прямоточною видачею спіненої вибухової композииії до місия застосування.

Запропоновано добір компонентного складу водонаповнених спінених вибухових композицій низької щільності, наведено їхні фізико-технічні та динамічні характеристики.

Досліджено динамічні та фізико-технічні характеристики малощільних спінених вибухових композицій і встановлено, щзо мінімальна швидкість детонації цих ВР у відкритих зарядах та 6 зарядах у жорсткій оболонщі менше ніж мінімальна швидкість детонації у штатного амоніту № 6ЖВ; бризантність спінених вибухових композищій не перевищує $(10-11)^{*} 10^{-3}$ м, шуо практично вдвічі менша, ніж у ігданіту і втричі менша, ніж у амоніту № 6ЖВ; дещзо більший час наростання тиску в імпульсі до максимуму у спінених вибухових композицій порівняно з ігданіторм; тиск на фронті хвилі у спінених вибухових композицій у 6-7 разів менший, ніж у амоніту № 6ЖВ відповідно $i$ значно менша швидкість наростання тиску в імпульсі. Такі параметри вибухового імпульсу ВР дають можливість використовувати спінені вибухові композиції для рівномірного ущільнення просадних лесових трунтів на необхідну потужність та при розмінуванні мінних полів.

Ключові слова: просадні трунти; водонаповнена спінена вибухова композиція; пристрій; аміачна селітра; поверхнево-активні речовини.

Постановка проблеми у загальному вигляді та її зв'язок з важливими практичними завданнями. В Україні просадні нестійкі грунти займають 65 \% території, більшість якої відведена під забудову. В умовах освоєння місцевості суттєвою проблемою є високий ступінь просідання (до 40 \%) особливо лесових грунтів в умовах природного або техногенного зволоження. Існуючі способи ліквідації просадних властивостей лесових грунтів класифікуються на фізико-хімічні і фізико-механічні.

Фізико-хімічні способи ліквідації просадних властивостей лесових грунтів забезпечують високу міцність грунтів після їх застосування, однак висока вартість закріплення грунту, необхідність застосування спеціального обладнання, обмежена глибина обробки, відсутність надійного методу контролю обмежує широке застосування цих методів у будівельній практиці. Тому вони застосовуються, головним чином, при відновленні аварійних будівель та спорудженні відповідальних цивільних і промислових споруд [1].

Досвід підготовки основ під будівництво показує, що найбільш широке застосування отримали механічні методи ліквідації просадних властивостей грунтів (ущільнення важкими трамбівками і грунтові подушки). Низька вартість робіт і проста технологія цих методів забезпечили широке впровадження їх в будівельну практику [2].

Однак при цьому необхідно виокремити ряд негативних факторів: сезонність проведення робіт, нерівномірність ущільнення, відсутність спеціального обладнання, значні терміни виконання робіт, придатність переважно для грунтових умов I типу просідності.

Проста технологія глибинних вибухів може забезпечити широке застосування методу в практику будівництва при подальшому вдосконаленні технології виконання вибухових робіт 3 врахуванням параметрів вибухових речовин.

(C) В.В. Бойко, О.В. Ган, В.Г. Кравець, А.Л. Ган, 2019 
Удосконалення вибухової технології має бути спрямоване на розробку нових низькошвидкісних вибухових сумішей низької щільності з метою отримання необхідного рівномірного ущільнення по всій площі на необхідну глибину з можливістю керування сейсмічним ефектом вибуху. Тому розроблення способу приготування спіненої вибухової композиції та пристрою для іï приготування $\epsilon$ актуальним завданням.

Аналіз останніх досліджень та публікацій. Необхідність ліквідації просідання всієї товщі, особливо в грунтових умовах II типу просідності, посприяла застосуванню методів ущільнення з використанням енергії вибуху.

Відомо, що ущільнення грунтів вибухами було розпочато ще у 1936 р. М.М. Масловим i Н.А. Філімоновим при будівництві Верхньо-Свирскої ГЕС [3]. Однак велика кількість тріщин, що виникли внаслідок недостатнього водонасичення ущільнюваних грунтів, призвела до критичного ставлення щодо цього методу.

Пізніше, в 1939-1940рр., серією глибинних вибухів були успішно ущільнені піщані грунти в основі земляної греблі «Франклін» в США.

У 1951 р. В.А. Флорін запропонував ущільнити піщану основу однієї з гребель глибинними вибухами. Рідкісне застосування методу глибинних вибухів і їх занадто короткі описи не дозволяли призначити масу зарядів, глибину їх закладання, розташування в плані і технологію проведення робіт [4].

Івановим П.Л. була розроблена методика ущільнення піску груповими зарядами і ущільнена дослідна ділянка на одному з островів Волги.

У 1954-1956 рр. під керівництвом Г.М. Ляхова на будівництві Волзької ГЕС були проведені великі польові дослідження дії вибуху в водонасичених піщаних грунтах. Істотним результатом роботи було детальне вивчення властивостей ударних хвиль у водонасичених пісках і вплив на ці параметри грунтового середовища. Позитивні результати ущільнення незв'язаних грунтів вибухами дозволили приступити до вивчення можливості їх застосування для ліквідації просадних властивостей лесових грунтів.

У 1964 р. успішно пройшов виробничий експеримент, запропонований I.М. Литвиновим, метод ущільнення попередньо замочених лесових грунтів глибинними вибухами [5].

При цьому способі ущільнення просадних грунтів можна виробляти на практично будь-яку глибину (10-30 м і більше). Здійснюється воно шляхом попереднього регульованого замочування нагнітанням води через спеціальні дренажні поглинаючі свердловини за умови доведення ущільнюваної товщі грунту до граничної вологості, яка вводить його в нестійкий стан.

Характерним для способу глибинного ущільнення просадних грунтів $\epsilon$ буріння вертикальних вибухових і нагнітальних свердловин із застосуванням металевих обсадних труб, що істотно ускладнює технологію проведення ущільнюючих робіт.

У гідромеліоративному будівництві застосована також технологія ущільнення просадних грунтів 3 використанням подовжених горизонтальних зарядів. У зарубіжній практиці також відомі роботи щодо форсованого ущільнення грунтів за допомогою енергії вибуху, де спостерігається висока ефективність цієї технології [6-8]. Беручи до уваги, що метод ущільнення просадних лесових грунтів за допомогою енергії вибухів застосовується на забудованих територіях, особливої важливості набуває питання управління вибуховим імпульсом 3 метою зниження шкідливого сейсмічного впливу на навколишні споруди. При розробці родовищ корисних копалин існує потреба в ущільнені грунтів при ведені розкривних робіт, що забезпечує стійкість бортів кар'єрів [13-24]. Актуальним для вирішення цієї проблеми є розроблення нових низькошвидкісних вибухових сумішей з менш інтенсивним тривалим імпульсом для забезпечення рівномірного ущільнення на необхідну товщу просадних лесових грунтів.

Метою $є$ розроблення пристрою для приготування водонаповненої спіненої композиції та добір компонентів спінених вибухових композицій.

Викладення основного матеріалу. Традиційно водонаповнені спінені вибухові композиції складаються $з$ аміачної селітри, поверхнево-активних речовин (ПАР) і води [9]. Композиції такого типу призначалися для ведення робіт у гірничорудній промисловості в шпурових і накладних зарядах незначної площі при руйнуванні негабариту, видобутку штучного каменю та розмінуванні мінних полів. Приготування таких композицій полягає у змішуванні ПАР 3 водою, а потім 3 аміачною селітрою механічним шляхом, що призводить до спінення суміші. Час перемішування становить 15-25 хв [10].

При застосуванні водонаповнених спінених вибухових композицій для ущільненя просадних нестійких грунтів необхідно забезпечити відповідну продуктивність і рівень безпеки робіт при виготовленні значних об'ємів готового продукту для великих зарядів.

Для вирішення наведених вище завдань запропоновано пристрій, принцип роботи якого полягає в інтенсифікації процесу аерації великих об’ємів продукту і підвищенні безпеки робіт [11].

Поставлені цілі досягаються тим, що механічне змішування розчину ПАР і аміачної селітри проводять у низькошвидкісному режимі без спінювання суміші подачею цієї суспензії під тиском до об’єкта проведення підривних робіт та дозованою аерацією його за рахунок ежектування повітря потоком суміші 3 прямоточною видачею спіненої вибухової композиції до місця застосування . 
Цим досягається підвищення безпеки робіт, оскільки неспінена суміш розчину ПАР і аміачної селітри не чутлива до удару і тертя, а вибухові властивості цієї суспензії проявляються тільки після насичення суміші бульбашками повітря при виході потоку піносуспензіi з ежектора. Крім того, ежекторний прямоточний метод дозволяє виробляти значні об'єми спіненого вибухового композиту.

Зазначений спосіб здійснюється за допомогою пристрою (рис. 1), який включає в себе бункер аміачної селітри, ємності з ПАР, водою і розчином ПАР, механічний змішувач. Особливістю цього пристрою є те, що він містить низькошвидкісний механічний змішувач, накопичувальну ємність, насос, сопло, ежектор, вентиль-тримач повітря і пінний ствол.

Пристрій працює таким чином. Селітра з бункера 1 надходить у змішувач 5, в який дозується розчин ПАР 3 ємності 4. Готова суспензія надходить у накопичувальну ємність 6. Насосом 7 суспензія при необхідності подається під тиском в сопло 8. Швидкісний потік суспензії надходить в ежектор 9 і засмоктує повітря, що надходить 3 атмосфери через вентиль-дозатор 10. Потік аерується, тобто насичується високодисперсними бульбашками повітря. Отримана піносуспензія надходить у пінний ствол 11 і вже як спінена вибухова композиція подається безпосередньо до місця ведення вибухових робіт.

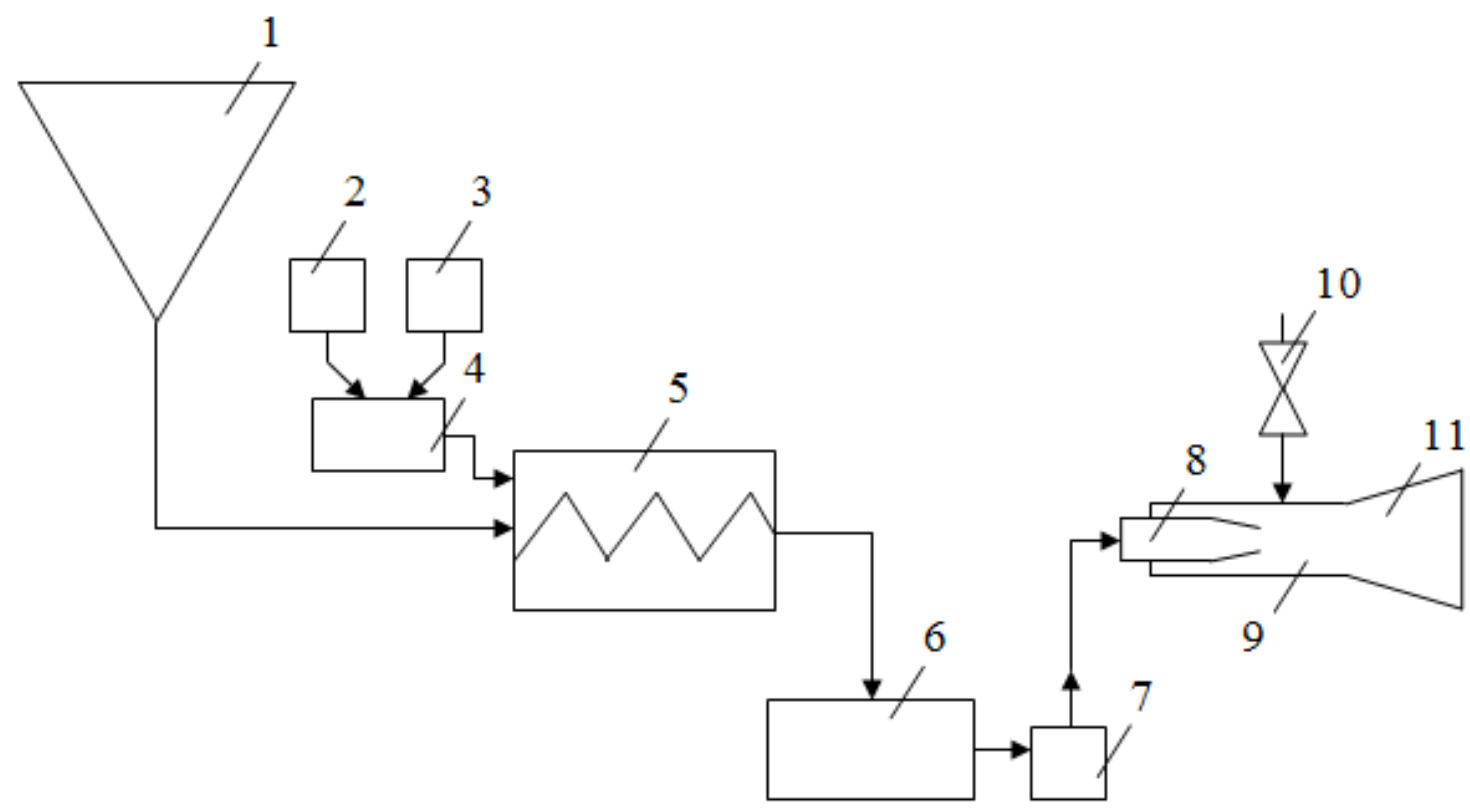

Рис. 1. Загальний вигляд пристрою для приготування водонаповненої спіненої вибухової композицї:

1 - бункер аміачної селітри, 2 - ємність ПАР, 3 - ємність води, 4-ємність водного розчину ПАР,

5 - низькообертовий механічний змішувач, 6 - накопичувальна ємність суспензї̈, 7 - насос, 8 - сопло, 9 - ежектор, 10 - вентиль-дозатор повітря, 11 - пінний ствол

Для забезпечення необхідного рівномірного ущільнення по всій площі на необхідну глибину запропоновано добір компонентного складу водонаповнених спінених вибухових композицій низької щільності на основі аміачної селітри, ПАР і води (табл. 1).

Піноутворювачі є поверхнево-активними речовинами першого класу на основі низькомолекулярних 3'єднань дифільного характеру, що мають гідрофільну частину (одну або кілька полярних груп, наприклад $\left.-\mathrm{OH},-\mathrm{COOH},-\mathrm{SO}_{3} \mathrm{H},-\mathrm{OSO}_{3} \mathrm{H}, \mathrm{COOMe}, \mathrm{N}^{+}\left(\mathrm{CH}_{3}\right)_{3} \mathrm{~J}^{-},-\mathrm{NH}_{2}\right)$ і гідрофобний аліфатичний ланцюг, іноді містять ароматичну групу.

За хімічними властивостями ПАР поділяються на аніоноактивні (наприклад, солі карбонових кислот, алкілсульфати, алкілсульфонати), катіоноактивні (наприклад, четвертинні амонієві основи, солі амінів) і неіоногенні (спирти, ефіри тощо).

ПАР - це багатоатомні органічні молекули, тому головним є питання про взаємозв'язок між будовою молекул і їх поверхнево-активними властивостями. Згідно з правилом Траубе, при збільшенні числа атомів вуглецю в алкільному ланцюгу поверхнева активність зростає в 3,2 на кожну групу $=\mathrm{CH}_{2}$. Причини, що обумовлюють таку поведінку ПАР, пояснюються тим, що поверхнева активність визначається роботою адсорбції, тобто збереженням енергії від переходу молекули ПАР з об'єму фази на поверхню, яка на одну метиленову групу становить 3 кДж/моль. Звідси ряд дослідників робить висновки, що кожна група $=\mathrm{CH}_{2}$ розташована по відношенню до поверхні так само, як будь-яка інша група в ланцюзі, а це може бути тільки при горизонтальному розташуванні.

ПАР першого класу належать до колоїдних або міцелярнорозчинних, другого класу - до неколоїдних або молекулярнорозчинних. Перше застосування ПАР першого класу знайшли місце як миючі засоби, емульгатори і піноутворювачі. Неколоїдні ПАР застосовують як співемульгатори або стабілізатори ПАР. 
Таблиияя 1

Компонентний склад і характеристики водонаповнених спінених вибухових композицій низької щуільності

\begin{tabular}{|c|c|c|c|c|c|}
\hline \multirow[b]{2}{*}{$\begin{array}{l}\text { № } \\
\text { 3/II }\end{array}$} & \multirow[b]{2}{*}{ Компоненти ВР } & \multicolumn{4}{|c|}{ Вміст компонентів, мас. \% } \\
\hline & & $\begin{array}{l}\text { Суміш I } \\
\text { по а. с. } \\
1436448\end{array}$ & $\begin{array}{l}\text { Суміш II } \\
\text { по а. с. } \\
1531401\end{array}$ & $\begin{array}{l}\text { Суміш III } \\
\text { по a. c. } \\
1561483\end{array}$ & $\begin{array}{l}\text { Суміш IV } \\
\text { по а. c. } \\
1600303\end{array}$ \\
\hline 1 & Аміачна селітра & $92,0-93,3$ & $89,8-92,9$ & $86,5-88,5$ & $90,5-91,5$ \\
\hline 2 & $\begin{array}{l}\text { Сульфосолі - контакт чорний } \\
\text { нейтралізований, рафінований }\end{array}$ & $2,0-4,0$ & $2,0-4,0$ & - & - \\
\hline 3 & Рафінований алкіларілсульфонат & $1,5-3,5$ & - & $5,0-7,0$ & $5,0-7,0$ \\
\hline 4 & Етилендіамін & $0,2-0,5$ & - & - & - \\
\hline 5 & Алкілсульфати натрію & - & $1,0-3,0$ & - & - \\
\hline 6 & Контакт Петрова & - & - & $1,0-3,0$ & - \\
\hline 7 & Карбоксиметилцелюлоза & - & - & $0,5-1,5$ & - \\
\hline 8 & Алкілсульфати натрію (вторичн.) & - & - & - & $1,0-3,0$ \\
\hline 9 & Поліакриламід & - & - & - & $0,5-1,5$ \\
\hline 10 & Вода & $1,0-2,0$ & $2,0-5,0$ & $3,0-4,0$ & - \\
\hline \multicolumn{6}{|c|}{ Характеристики } \\
\hline 1 & Щільність, кг $/ \mathrm{M}^{3}$ & $500-800$ & $500-800$ & $200-350$ & $200-250$ \\
\hline 2 & Кратність піни & $1,8-3,0$ & $1,8-3,0$ & $3,6-4,0$ & $3,6-4,2$ \\
\hline \multirow[t]{2}{*}{3} & $\begin{array}{c}\text { Критичний діаметр, } 10^{-3} \text { м } \\
\text { - відкритого заряду }\end{array}$ & $50-70$ & $50-80$ & $50-70$ & $60-90$ \\
\hline & - в жорсткій оболонці & $30-40$ & $30-40$ & $30-40$ & $30-40$ \\
\hline \multirow[t]{2}{*}{4} & $\begin{array}{c}\text { Фізична стабільність в інтервалі } \\
\text { температур від }+30 \text { до }-10{ }^{\circ} \mathrm{C}: \\
\text { - у відкритій посудині, год. }\end{array}$ & $9-10$ & $10-12$ & $14-17$ & $20-24$ \\
\hline & - у закритій посудині, діб & $5-7$ & $6-7$ & $5-8$ & - \\
\hline 5 & Теплота вибуху, $10^{3}$ Дж/кг & $3500-3770$ & $3520-3780$ & $3500-3700$ & $3500-3700$ \\
\hline \multirow[t]{2}{*}{6} & $\begin{array}{c}\text { Мінімальний ініціюючий імпульс } \\
\text { - відкритого заряду, кг ТНТ }\end{array}$ & $0,01-0,03$ & $0,01-0,03$ & $0,01-0,03$ & $0,01-0,02$ \\
\hline & - в жорсткій оболонці & ЕД-8 & ЕД-8 & ЕД-8 & ЕД-8 \\
\hline 7 & Льодостійкість & \multicolumn{4}{|c|}{ нельодостійкі } \\
\hline
\end{tabular}

Тому більшість практично важливих промислових емульгаторів і піноутворювачів є складними сумішами поверхнево-активних речовин. У результаті на межі розподілу емульсій або піни відбувається адсорбція відразу кількох речовин. Однак процес адсорбції навіть двох ПАР вивчений недостатньо, що суттєво ускладнює завдання отримання стабільної піни.

Піна - висококонцентрована гетерогенна система газ-рідина, в якій бульбашки газу розділені тонкими плоскими прошарками рідини, що утворюють замкнуту решітку. Від висококонцентрованої емульсії піни відрізняються тим, що рідина дисперсної фази замінена газом.

Принципово причини стійкості пін ті самі, що й у висококонцентрованих емульсій, однак наявність плоских плівок додає ряд особливостей у багатьох властивостях пін.

На відміну від емульсій, які в ряді випадків стійкі протягом багатьох днів, піни за невеликим винятком (тверді піни) стійкі лише протягом декількох годин [12].

Значно менша стійкість пін, порівняно з емульсіями, обумовлена тим, що плівки пін, маючи мікронну товщину, легко піддаються зовнішнім впливам (випаровуванню та ін.). Лише в умовах герметизації в зарядній порожнині піни наближаються за стійкістю до висококонцентрованих емульсій, стабілізованих тими ж ПАР, в яких плівки неперервної фази захищені від випаровування та інших впливів рідиною дисперсної фази.

У нашому випадку, коли рідка фаза представлена суспензією селітри з водою, піносуспензія більш стійка, оскільки рідина дисперсної фази випаровується, а піна залишається у вигляді твердого каркаса частинок селітри, зцементованих ПАР.

Як видно із зазначених даних, густина вибухових композицій за рахунок аерації суміші регулюються від 150 до 800 кг/м³ , критичний діаметр зарядів вибухових речовин у жорсткій оболонці становить (30$40)^{*} 10^{-3}$ м. Заряди в жорсткій оболонці чутливі до детонатора ЕД-8.

Фізична стабільність аерованої системи в діапазоні температур від +30 до $-10{ }^{\circ} \mathrm{C}$ у відкритій посудині становить 9-24 год, в закритій посудині - порядка 5-8 діб. При зниженні температури до $-15{ }^{\circ} \mathrm{C}$ стабільність ВР різко падає за рахунок замерзання оболонок пінних комірок і руйнування піни. 
Льодостійкість спінених ВР низька, оскільки піносуспензія розчиняє лід, обводнюється і втрачає стабільність.

Динамічні характеристики спінених вибухових композицій досліджувалися, порівняно 3 малощільними ВР, на основі АС/СФ/ППС. При цьому вивчалася детонація відкритих зарядів діаметром $(50-90)^{*} 10^{-3}$ м. Бризантність зарядів вивчалася за ГОСТ 5984-80. У всіх випадках досліджувалися свіжоприготовлені спінені вибухові композиції, оскільки піносистеми змінюють свої характеристики в часі.

Динамічні характеристики спінених ВР наведені в таблиці 2. 3 наведених даних видно, що швидкість детонації відкритих зарядів ВР становить $(1,2-2,4) * 10^{3}$ м/с, малощільної сипучої ВР на основі АС/СФ/ППС - $(1,0-1,5)^{*} 10^{3}$ м/с. Відповідно бризантність спінених вибухових композицій дещо вища, порівняно 3 сипучою малощільною ВР,$-(7 \ldots 11)^{*} 10^{-3}$ м проти $(5 \ldots 8) * 10^{-3}$ м.

Таблиця 2

Динамічні характеристики спінених ВР

\begin{tabular}{|c|c|c|c|c|c|c|c|}
\hline \multirow[b]{2}{*}{$\begin{array}{l}\text { № } \\
\text { 3/II }\end{array}$} & \multirow[b]{2}{*}{$\begin{array}{l}\text { Найменування } \\
\text { характеристики }\end{array}$} & \multirow[b]{2}{*}{ Од. вим. } & \multicolumn{5}{|c|}{ Найменування ВР } \\
\hline & & & $\begin{array}{l}\text { Суміш } \\
\text { I }\end{array}$ & $\begin{array}{l}\text { Суміші } \\
\text { II }\end{array}$ & $\begin{array}{c}\text { Суміш } \\
\text { III }\end{array}$ & $\begin{array}{l}\text { Суміші } \\
\text { IV }\end{array}$ & $\begin{array}{c}\text { Малощільна ВР } \\
\text { АС/СФ/ППС }\end{array}$ \\
\hline \multirow{2}{*}{1} & $\begin{array}{c}\text { Швидкість детонації: } \\
\text { - відкритий заряд }\end{array}$ & \multirow{2}{*}{$10^{3} \mathrm{M} / \mathrm{c}$} & $1,0-2,4$ & $1,0-2,5$ & - & - & $1,0-1,5$ \\
\hline & $\begin{array}{c}\text { - заряд у жорсткій } \\
\text { оболонці }\end{array}$ & & $1,1-3,2$ & $1,1-3,0$ & $1,9-2,1$ & $2,0-2,2$ & $1,4-2,1$ \\
\hline 2 & $\begin{array}{c}\text { Бризантність у } \\
\text { сталевому кільці }\end{array}$ & $10^{-3} \mathrm{M}$ & $7-11$ & $7-11$ & $7-9$ & $7-8$ & $5-8$ \\
\hline 3 & $\begin{array}{c}\text { Час зростання тиску в } \\
\text { імпульсі }\end{array}$ & $10^{-6} \mathrm{c}$ & $40-50$ & $45-50$ & $50-55$ & $50-60$ & $55-60$ \\
\hline 4 & Тиск на фронті хвилі & $10^{9} \Pi \mathrm{a}$ & $0,7-0,8$ & $0,7-0,8$ & $0,6-0,7$ & $0,5-0,7$ & $0,5-0,6$ \\
\hline 5 & $\begin{array}{c}\text { Швидкість зростання } \\
\text { тиску } \\
\end{array}$ & $10^{14} \Pi \mathrm{a} / \mathrm{c}$ & $0,14-0,20$ & $0,14-0,17$ & $0,11-0,14$ & $0,08-0,14$ & $0,08-0,11$ \\
\hline
\end{tabular}

Тривалість наростання тиску в імпульсі до максимуму у досліджених вибухових композиціях близька і складає $(40-60)^{*} 10^{-6}$ c. Тиск на фронті хвилі у спінених ВР на $(0,1-0,2) * 10^{9}$ Па вище, ніж у сипучих малощільних ВР.

Швидкість наростання тиску в імпульсі у спінених ВР становить $(0,08-0,20) * 10^{14}$ Па/с, у сипучих сумішей - $(0,08-0,11) * 10^{14}$ Па/с.

Дослідження динамічних характеристик спінених ВР змінної щільності показує, що описані спінені вибухові композиції можуть ефективно використовуватися для рівномірного ущільнення просадних лесових грунтів на необхідну потужність та при розмінуванні мінних полів.

Висновки та перспективи подальших досліджень:

1. Запропоновано спосіб приготування водонаповненого спіненого вибухового композиту, який включає змішування ПАР з водою, введення аміачної селітри, перемішування суміші механічним шляхом, який полягає в тому, що з метою інтенсифікації процесу аерації великих об'ємів продукту і підвищення безпеки робіт механічне змішання розчину ПАР і селітри проводять в низькошвидкісному режимі без спінювання суміші, далі суспензія подається під тиском до об'єкта проведення підривних робіт та дозовано аерується за рахунок ежектування повітрям потоку суміші з прямоточною видачею спіненого вибухового композиту на місце застосування.

2. Добрано компонентний склад малощільних спінених вибухових композицій місцевого приготування на основі порошкоподібних і рідких ПАР.

3. Досліджено динамічні характеристики малощільних спінених вибухових композицій (щільністю від 200 до 800 кг $\left./ \mathrm{m}^{3}\right)$. Встановлено, що мінімальна швидкість детонації цих ВР у відкритих зарядах становить $(1,0 \ldots 1,4) * 10^{3} \mathrm{M} / \mathrm{c}$, а в зарядах в жорсткій оболонці - $(1,4 \ldots 1,6) * 10^{3} \mathrm{M} / \mathrm{c}$, в той час, як у штатного амоніту № $6 Ж \mathrm{~B}-(3,2 \ldots 3,5) * 10^{3} \mathrm{~m} / \mathrm{c}$.

4. Бризантність спінених вибухових композицій не перевищує $(10-11)^{*} 10^{-3} \mathrm{M}$, у ігданіту вона становить $(15 \ldots 20)^{*} 10^{-3}$ м, а у амоніту № 6ЖВ $-(24 \ldots 29) * 10^{-3}$ м.

5. Час наростання тиску в імпульсі до максимуму у спінених вибухових композицій досягає $(45 \ldots 60)^{*} 10^{-6}$ с, відповідно у ігданіту $(30 \ldots 40)^{*} 10^{-6}$ с та у амоніту № 6 ЖВ $-(4 \ldots 5) * 10^{-6}$ c.

6. Тиск на фронті хвилі у спінених вибухових композицій не перевищує $(0,6 \ldots 0,9)^{*} 10^{9}$ Па, в той час, як у амоніту № 6ЖВ він досягає $(5,5 \ldots 6,1) * 10^{9}$ Па. 
7. Швидкість наростання тиску в імпульсі у спінених вибухових композиціях становить $(0,08-$ 0,20)*10 $10^{14}$ Па/с, проти $(11-15) * 10^{14}$ Па/с у амоніту № 6ЖВ.

8. Керування параметрами вибухового імпульсу шляхом використання ВР регульованої щільності забезпечує можливість рівномірного ущільнення просадних лесових грунтів на необхідну потужність та може бути використане при розмінуванні мінних полів.

\section{Список використаної літератури:}

1. Смагулова Л.К. Виды и способы закрепления грунтов / Л.К. Смагулова // Молодой ученый. - 2017. - № 18. C. 80-83 [Електронний ресурс]. - Режим доступу : https://moluch.ru/archive/152/43141/.

2. Подготовка оснований зданий и сооружений, строящихся на замедленно-просадочных грунтах I и II типа по просадочности / А.Н. Богомолов, Ю.И. Олянский, Л.А. Анисимов и др. // Вестник Волгоград. гос. арх.-строит. ун-та / Строительство и архитектура. - 2015. - № 41 (60). - С. 14-23.

3. Маслов Н.Н. Условия устойчивости водонасыщенных песков / Н.Н. Маслов. - М. : Госэнергоиздат, 1959.

4. Інженерна геологія. Механіка грунтів, основи і фундаменти : підручник / М.Л. Зоценко, В.І. Коваленко, А.В. Яковлєв та ін. - Полтава : ПНТУ, 2003. - 446 с.

5. Кук М.A. Наука о промышленных взрывчатых веществах / М.A. Кук. - М. : Недра, 1980. - 454 с.

6. Minaev O.P. Effective Blasting Method of Compacting Sand Foundation Beds for Various Structures / O.P. Minaev // Power Technology and Engineering. - 2018. - Vol. 51, Issue 5, P. 507-512.

7. Shakeran M. Geotechnical Aspects of Explosive Compaction / M.Shakeran, A.Eslami // Shock and Vibration. -2016.

8. А. с. 572094 СССР. Способ уплотнения просадочных лессовых грунтов / СКТБ Института геофизики АН УССР/ А.А. Вовк, В.Г. Кравеи, Л.И. Демещук и др. - МКИ Е02Д 3/10, 1976.

9. А. с. СССР № 1403565, кл. С06 В 31/28, 1985.

10. Кривцов Н.В. Технология производства малоплотных ВС / Н.В. Кривиов, С.А. Сторчак // Строительные материалы и конструкции. - К., 1994. - № 2. - С. 30-31.

11. Патент на корисну модель UA № 122425, МПК: Е21C 37/00. Пристрій для приготування водонаповненої вспіненої вибухової композиції / В.В. Бойко, Ю.П. Приходько, В.К. Гончар, К.С. Золотухін, Ю.Ю. Орлов, В.І. Плужник, О.В. Ган. - 10.01.2018.

12. Абрамзон А.А. Поверхностно-активные вещества. Свойства и применение / А.А. Амбразон. - Ленинград : Химия, 1981. - $304 \mathrm{c}$.

13. Виймально-навантажувальні роботи на кар'єрах : навч. посібник / В.В. Коробійчук, В.Г. Кравецьь, С.С. Іськов та ін. - Житомир : ЖДТУ, 2017. - 440 с.

14. Korobiichuk V. Study of Ultrasonic Characteristics of Ukraine Red Granites at Low Temperatures / V.Korobiichuk // International Conference on Systems, Control and Information Technologies. - America : Springer International Publishing, 2016. - P. 653-658.

15. Cluster analysis of fracturing in the deposits of decorative stone for the optimization of the process of quality control of block raw material / R.Sobolevskyi, N.Zuievska, V.Korobiichuk and other // Eastern-European Journal of Enterprise Technologies. - 2016. - Issue 5/3 (83). - P. 21-29.

16. Exploring the efficiency of applying fractal analysis for the process of decorative stone quality control / R.Sobolevskyi, V.Korobiichuk, S.Iskov and other // Eastern-European Journal of Enterprise Technologies. - 2016. Vol. 6/3 (84). - P. 32-40.

17. Коробійчук В.В. Дослідження шляхів мінімізації витрат при буровибуховому способі видобування блоків декоративного каменя / В.В. Коробійчук, Р.В. Соболевський, О.А. Зубченко // Вісник ЖДТУ : Технічні науки. 2006. - № 4 (39). - С. 301-308

18. Закусило Р.В. Засоби ініціювання промислових зарядів вибухових речовин : монографія / Р.В. Закусило, В.Г. Кравещь, В.В. Коробійчук. - Житомир : ЖДТУ, 2011. - 212 с.

19. Кравещь В.Г. Фізичні процеси прикладної геодинаміки вибуху : монографія / В.Г. Кравещь, В.В. Коробійчук, B.В. Бойко. - Житомир : ЖДТУ, 2015. - 408 с.

20. Investigation of leznikovskiy granite by ultrasonic methods / I.Korobiichuk, V.Korobiichuk, P.Hájek and other // Archives of Mining Sciences. - 2018. - T. 63. - № 1. - P. 75-82.

21. Weakening of rock strength under the action of cyclic dynamic loads / V.Korobiichuk, V.Kravets, R.Sobolevskyi and other // Eastern-European Journal of Enterprise Technologies. - 2018. - № 2/5 (92). - P. 20-25 [Electronic resource]. - Access mode : https://doi.org/10.15587/1729-4061.2018.127847.

22. Ефективність зарядів різних конструкцій при деформуванні та руйнуванні металевих перепон / Ю.І. Войтенко, В.Г. Кравещь, А.Шукюров та ін. // Вісник ЖДТУ : Технічні науки. - 2018. - № 1 (81). - С. 223 231.

23. Коробійчук В.В. Руйнування гірських порід та безпека вибухових робіт : підручник / В.В. Коробійчук, В.О. Соколовський, С.С. Іськов. - Житомир : ЖДТУ, 2019. - 332 с.

24. Крайові ефекти вибуху зарядів складної форми / В.Г. Кравець, А.Шукюров, П.А. Гонтар та ін. // Вісник ЖДТУ : Технічні науки. - 2018. - № 2 (82). - С. 247-252.

\section{References:}

1. Smagulova, L.K. (2017), «Vidy i sposoby zakrepleniya gruntov», Molodoi uchenyi, No. 18, pp. 80-83, [Online], available at: https://moluch.ru/archive/152/43141/

2. Bogomolov, A.N., Olyanskii, Yu.I., Anisimov, L.A. i dr. (2015), «Podgotovka osnovanii zdanii i sooruzhenii, stroyashchikhsya na zamedlenno-prosadochnykh gruntakh I i II tipa po prosadochnosti», Vestnik Volgograd. gos. arkh.-stroit. un-ta, No. 41 (60), pp. 14-23.

3. Maslov, N.N. (1959), Usloviya ustoichivosti vodonasyshchennykh peskov, Hosjenerhoizdat, Moscow. 
4. Zocenko, M.L., Kovalenko, V.I., Jakovljev, A.V. ta in (2003), Inzhenerna geologija. Mehanika g'runtiv, osnovy $i$ fundamenty, pidruchnyk, PNTU, Poltava, $446 \mathrm{p}$.

5. Kuk, M.A. (1980), Nauka o promyshlennykh vzryvchatykh veshchestvakh, Nedra Publ., M., 454 p.

6. Minaev, O.P. (2018), «Effective Blasting Method of Compacting Sand Foundation Beds for Various Structures», Power Technology and Engineering, Vol. 51, Issue 5, pp. 507-512.

7. Shakeran, M. and Eslami, A. (2016), «Geotechnical Aspects of Explosive Compaction», Shock and Vibration.

8. Vovk, A.A., Kravets, V.H. and Demeshchuk, L.Y (1976), Sposob uplotneniya prosadochnykh lessovykh gruntov, A. s. 572094 (SSSR), SKTB Instituta heofiziki AN USSR. MKY E02D 3/10.

9. A. s. SSSR (1985), No. 1403565, kl. S06 V 31/28.

10. Krivtsov, N.V. and Storchak, S.A. (1994), «Tekhnologiya proizvodstva maloplotnykh VS», Stroitel'nye materialy i konstruktsii, K., No. 2, pp. 30-31.

11. Bojko, V.V., Pryhod'ko, Ju.P., Gonchar, V.K., Zolotuhin, K.S., Orlov, Ju.Ju., Pluzhnyk, V.I. and Gan, O.V. (2018), Prystrij dlja prygotuvannja vodonapovnenoi' vspinenoi' vybuhovoi' kompozycii', UA, Patent na korysnu model No. 122425, MPK: E21C 37/00.

12. Abramzon, A.A. (1981), Poverkhnostno-aktivnye veshchestva. Svoistva i primenenie, Khimiya, Leningrad, $304 \mathrm{p}$

13. Korobijchuk, V.V., Kravec', V.G., Is'kov, S.S. and other (2017), Vyjmal'no-navantazhuval'ni roboty na kar'jerah, navch. posibnik, ZhDTU, Zhytomyr, $440 \mathrm{p}$.

14. Korobiichuk, V. (2016), «Study of Ultrasonic Characteristics of Ukraine Red Granites at Low Temperatures», International Conference on Systems, Control and Information Technologies, Springer International Publishing, America, pp. 653-658.

15. Sobolevskyi, R., Zuievska, N., Korobiichuk, V. and other (2016), «Cluster analysis of $\mathrm{f}$ racturing in the deposits of decorative stone for the optimization of the process of quality control of block raw material», Eastern-European Journal of Enterprise Technologies, Issue 5/3 (83), pp. 21-29.

16. Sobolevskyi, R., Korobiichuk, V., Iskov, S. and other (2016), «Exploring the efficiency of applying fractal analysis for the process of decorative stone quality control», Eastern-European Journal of Enterprise Technologies, Vol. 6/3 (84), pp. 32-40.

17. Korobijchuk, V.V. Sobolevs'kij, R.V. and Zubchenko, O.A. (2006), «Doslidzhennja shljahiv minimizacii' vytrat pry burovybuhovomu sposobi vydobuvannja blokiv dekoratyvnogo kamenja», Visnyk ZhDTU, Tehnichni nauky, No. 4 (39), pp. 301-308.

18. Zakusilo, R.V., Kravec', V.G. and Korobijchuk, V.V. (2011), Zasoby inicijuvannja promyslovyh zarjadiv vybuhovyh rechovyn, monografija, ZhDTU, Zhytomyr, $212 \mathrm{p}$.

19. Kravec', V.G., Korobijchuk, V.V. and Bojko, V.V. (2015), Fizychni procesy prykladnoi' geodynamiky vybuhu, monografija, ZhDTU, Zhytomyr, 408 p.

20. Korobiichuk, I., Korobiichuk, V., Hájek, P., Kokeš, P. and other (2018), «Investigation of leznikovskiy granite by ultrasonic methods», Archives of Mining Sciences, Vol. 63, No. 1, pp. 75-82.

21. Korobiichuk, V., Kravets, V., Sobolevskyi, R. and other (2018), «Weakening of rock strength under the action of cyclic dynamic loads», Eastern-European Journal of Enterprise Technologies, No. 2/5 (92), pp. 20-25, [Online], available at: https://doi.org/10.15587/1729-4061.2018.127847

22. Vojtenko, Ju.I., Kravec', V.G., Shukjurov, A. and other (2018), «Efektyvnist' zarjadiv riznyh konstrukcij pry deformuvanni ta rujnuvanni metalevyh perepon», Visnyk ZhDTU, Tehnichni nauky, No. 1 (81), pp. 223-231.

23. Korobiichuk, V.V., Sokolovskyi, V.O. and Iskov, S.S. (2019), «Rujnuvannja girs'kyh porid ta bezpeka vybuhovyh robit», pidruchnyk, ZhDTU, Zhytomyr, $332 \mathrm{p}$.

24. Kravec', V.G., Shukjurov, A., Gontar, P.A. and other (2018), «Krajovi efekty vybuhu zarjadiv skladnoi' formy», Visnyk ZhDTU, Tehnichni nauki, No. 2 (82), pp. 247-252.

Бойко Віктор Вікторович - доктор технічних наук, професор Науково-дослідної лабораторії з проблем сейсмічної безпеки технологічних вибухів Інституту гідромеханіки Національної академії наук України.

Наукові інтереси:

- гірнича справа; промислова сейсмобезпека вибухів.

Ган Олена Валеріївна - аспірант Науково-дослідної лабораторії $з$ проблем сейсмічної безпеки технологічних вибухів Інституту гідромеханіки Національної академії наук України.

Наукові інтереси:

- гірнича справа; геоінженерія; вибухова справа.

Кравець Віктор Георгійович - доктор технічних наук, професор Національного технічного університету України «Київський політехнічний інститут імені Ігоря Сікорського».

Наукові інтереси:

- відкрита розробка родовищ корисних копалин; геоінженерія; вибухова справа.

Ган Анатолій Леонідович - кандидат технічних наук, доцент Національного технічного університету України «Київський політехнічний інститут імені Ігоря Сікорського».

Наукові інтереси:

- вибухові роботи; гірнича справа; геоінженерія. 